\title{
AN OVERVIEW ON IOT FOR FARMING: FOOD QUALITY AND SAFETY
}

\begin{tabular}{|c|c|c|c|}
\hline \multicolumn{4}{|c|}{$\begin{array}{l}\text { Mr. N.N.Saxena } \\
\text { /ersity, Mathura, Uttar Pradesh, India }\end{array}$} \\
\hline Journal & \multicolumn{3}{|c|}{$\begin{array}{l}\text { Samvakti Journal of Research in Information Technology } \\
\text { https://www.sjrit.samvaktijournals.com } \\
\text { Volume } 2 \text { Year of Volume } 2021 \text { Page No : } 49 \text { - } 56\end{array}$} \\
\hline Discipline & \multicolumn{3}{|l|}{ Internet of Things } \\
\hline Conference & \multicolumn{3}{|c|}{$\begin{array}{l}\text { A virtual international conference on redefining and transforming the role of higher } \\
\text { education in sustainable development }\end{array}$} \\
\hline Conference & \multicolumn{3}{|c|}{ Start Date: September 30, 2021} \\
\hline Dates & \multicolumn{3}{|c|}{ End Date : September 30, 2021} \\
\hline Institute Name & \multicolumn{3}{|c|}{$\begin{array}{l}\text { JAIN (Deemed-to-be University) in association with Council for Industrial } \\
\text { Innovation and Research }\end{array}$} \\
\hline $\begin{array}{l}\text { Date Received } \\
\text { ID } \\
\text { Dol }\end{array}$ & $\begin{array}{l}\text { November } 19,2021 \\
2021.02 .16 \\
10.46402 / 2021.02 .16\end{array}$ & $\begin{array}{l}\text { Publication Date } \\
\text { Paper Type } \\
\text { Dol URL }\end{array}$ & $\begin{array}{l}\text { : December } 11,2021 \\
\text { : Conference Paper } \\
\text { : https://dx.doi.org/10.46402/2021.02.16 }\end{array}$ \\
\hline
\end{tabular}

\section{ABSTRACT}

Food is primary source of energy for the all living things, therefore foods quality or safety have always been in short supply through history of mankind. The Internets of Things is the technology that aims to link everything, everywhere, at any time. By tracing or monitoring foods condition or live sharing's the acquire data with customers and FSC supervisor, IOT in the foods supply chains is thought to improve qualities of the lifes. The complete implementation of Internet of Things in the FSC is still in its early stages, and there is a lot of room for development. The goals of this articles is look at the potentials of using the Internet of Things (IoT) in agricultures to monitor and trace safety as well as quality of foods. The findings revealed that a smart phones camera can use to evaluate the cleanness of the food after a successful mobile applications for the foods freshness research was created. This information may be shared with all customers as well as supervisors via loT technology.

KEYWORDS: Agriculture, Farming, Food Quality, Food Safety, IoT. 


\section{INTRODUCTION}

For a variety of reasons, food safety or quality has been a significant worry and a heated subject all over the world in recent years, particularly in China. For example, the 2008 Sanlu melamine's milk powders crisis shook the globes owing to its impact on the thousands of infants, with many of them dying as a consequence. Another event that shocked the Chinese community as well as the rest of the world occurred in 2011, when beef from Shuanghui Groups (China's biggest meat suppliers) was found to contains chemical (Clenbuterol hydrochlorides) which is banned in the China. Foods quality or safety are attracting the attention of the both governments agencies or customers owing to the significant loss of states income as well as the health hazards to consumers posed by non-compliance with food regulations. As a result, it is critical to create technology that can ensure food safety across the whole food supply chain (FSC), which includes manufacturing, processing, packaging, transportation, storing, distribution, including consumer sale.

Many studies have been carried out across the globe with the development of the technologies such as the internets of thing (IOT) to assist companies in resolving foods quality or safety problems. IoT is the visions of being able to connect to everything at any time and from any location, and it is anticipated to dramatically alter our lives in the next years. "Things with identities or virtual personalities functioning in the smarts environments utilizing intelligents boundaries to interact or communicates with in societal, ecological, including users context," according to the European Commission. IoT technologies are seen to be capable of resolving problems of traceability, visibility, as well as controllability throughout the FSCs supply chain. For many years, IOT technologies have been used in the pharmaceutical sector to improve quality and keep medicines safe. In terms of managing factory staff members, food items, and giving valuable information to consumers, IOT will play part in addressing problems of food quality or safety, making it is simpler or more relaxed for the people to monitors or consumes foods with the confidences ${ }^{[1][2]}$.

Foods packaging is critical in preserving the safety of food throughout the supply chains. Conventional packaging is the designed to protects foods from changes in environment such as the temperature, humidity, lights, gaseous emission, and microbials assaults. Active packaging systems, on the other hand, are those that feature direct interaction between the packed food and the packing environments to offer protections and prolong the food's shelf lifespan. Actives packaging preserves packed foods by the incorporating actives component that release and absorb chemicals into or out of the food to maintain control of the conditions. Intelligent packaging, on the other hand, does not include any active ingredients. It does, however, have sophisticated mechanisms that interacts with the supervisors and customer to gives information's on the presents states of the meals. 
There are 2 kinds of smarts packaging device. The first are information carrier, such as barcode label as well as radio frequency identifications tags, as well as the second are package indicators, including time temperatures indicators and gases indicator, which are then used to monitors environmental changes. Fadables ink for the times, temperature regulation of the foods cleanness has been extensively utilized the printings of the freshness label on the foods containers ${ }^{[3]}$.

The idea is when the ink fades over time, it will indicate that the food is no longer fresh. Even as temperature fluctuates and the air reacts with both the label ink, the colour fades. The chemical makeup of the ink determines how quickly it changes color. The writing on the label has faded over times. Labels that indicate the presence of the a gas as just a result of a change inside the foodstuff condition within the package are known as gas indicator. The interaction of polyaniline films with ammonia released when seafood spoils was used as a sensing layers to check for food spoilage. As a result of fish degradation, ammonia created by bacterial development will react with PANI coatings. The reaction will cause the color of the film to shift. A new sticker sensors are based on the methyl's red adsorbed on the bacteria's celluloses membranes for broilers chickens freshness evaluation was described in as another smart packaging indication. To signify poultry spoiling, the color of the label changes from red to the yellow ${ }^{[4][5]}$. The $\mathrm{pH}$ level rises as the chicken spoils owing to an increase in spoilages volatiles amines, which fill headspace of foods packaging.

\section{IoT technology architecture:}

IoT technologies are made up of a variety of distributed energy resources that may be chosen based on the needs of various consumers and organizations across the world. The resources of IOT may be classified into three distinct levels, which are regarded to be the primary architectural layers of the IOT, when consider the verticals perspective of IOT technologies, which is focus on the actual implementation. The sensor layer, network layer, as well as application layer are the three layers, as shown in Figure 1. 


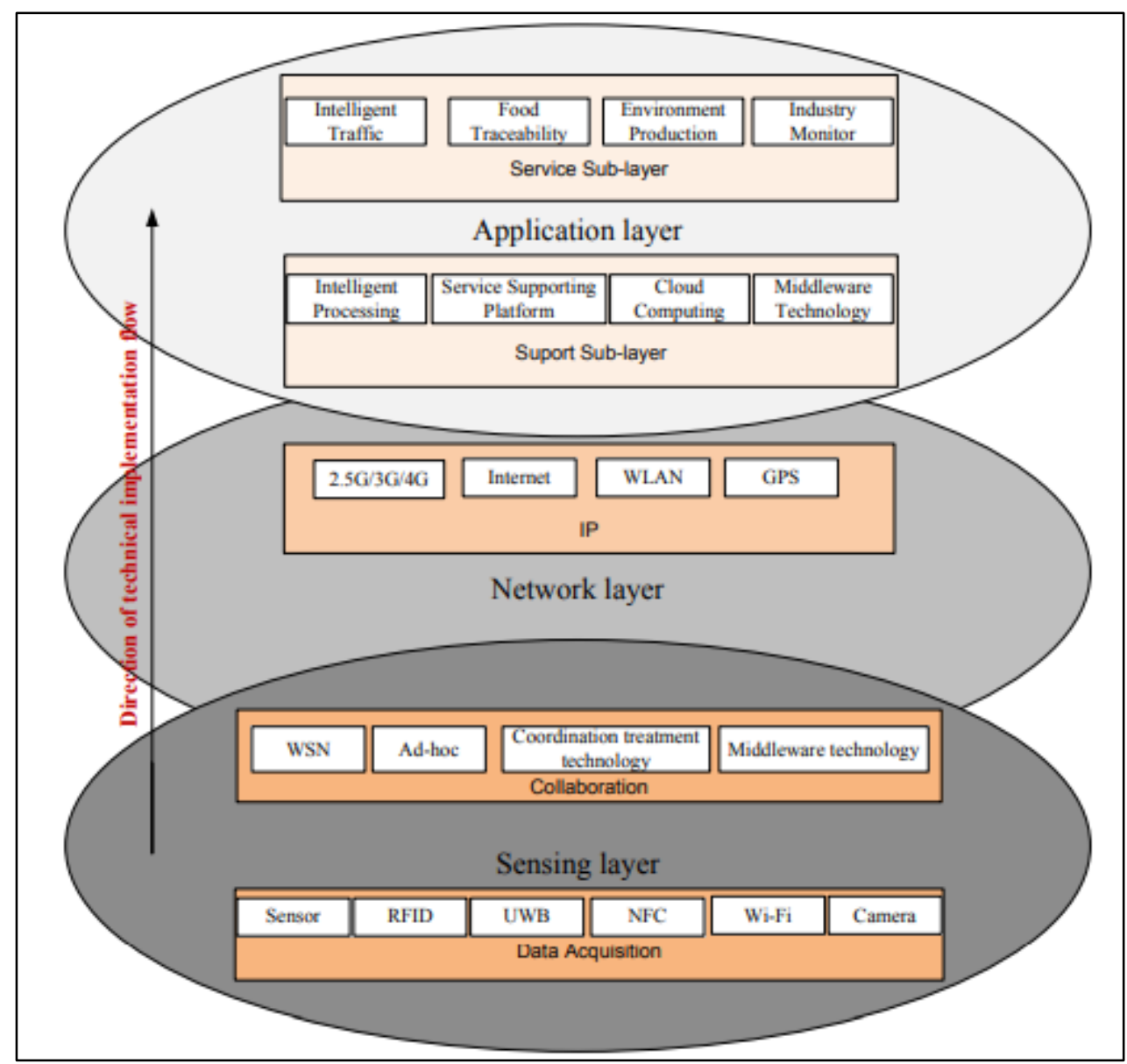

Figure 1: IoT architectural layers from the standpoint of technical implementation ${ }^{[6]}$.

Layer of sensing Based on the roles of the units, the sensing layer may be split into two levels. They are layers for data collection as well as collaboration. Phenomena from of physical worlds, such as temperatures, moisture, pressures, quantity, multimedia data, so on and so forth, are detected via devices such as sensors, or Ultra-wides Bands Near fields communications, WiFi, or camera in the data collection layer. The cooperation's layer, on the other hand, focuses on technology used in shorts distance information transfer, contexts awareness, including large data analysis. Sensor networks ad hoe coordination's treatments technology, or middleware technologies are all used in these applications. Layer of the network Backbones, mobiles communications, wireless lan (WLAN), satellites communications systems, Global positionings system (GPS), Bluetooth, and other network technologies have been utilized for many years. This network layer transmits the information collected by sensing layers to the applications layer ${ }^{[7][8]}$. 


\section{Layer of application:}

The applications layers is split into 2 parts. They are the supports sub layers or the service sub layers, respectively. The data is processed by the support sub-layer utilizing an intelligents processing units, or then sent to the user depending on the given request. Because of the enormous amount of the data involve the systems included high speed information processing cloud technology and peer to peer (P2P) middleware. The interface and platforms for specific public services are provided by the service sub layers. Security monitoring, disasters monitoring, vehicle schedule monitoring, or intelligents home appliance monitoring are examples of typical uses for this sub-layer ${ }^{[9]}$.

\section{Applications of loT technologies in foods supply chains:}

The Internets of Things (IOT) in the foods supply chains consists of a diverse set of the devices connected by a network of data exchange, tracking, or location systems. Foods producers, transportation companies, or foods consumer all have well defined connections across the supply chain. When the temperature inside the foods truck exceeds the required value, the system will sound an alert or send signals to refrigeration control to boost ventilations in order to the re adjust the temperature or keeps it in check. The same procedure is used to calculate additional characteristics such as humidity, gas concentrations, or ambient pressure, among others.

\section{Some loT sensing layer applications:}

As previously said, this layer is the initial layer that collects the data necessary for the Internet of things technology to operate. The follow-on are two example of the apps for detecting food freshness or determining foods authenticity. Development of a mobiles cameras app for the detecting foods freshness. The camera is the device that is used to collect data. A smartphone app has been created as parts of Internet of Thing technology employed in foods supply chains to take use of the mobiles camera of food customers for this purpose. This app checks the prawn's freshness as well as shows the findings on the consumer's smartphone screen. More information's regarding the mobile app may be found in a previous article we wrote. In conclusion, the developed smartphones app employs chromatic characteristics to quickly displays the cleanness levels of the items by the readings RGB colors from the colour changings label or comparing it to the colors of the $\mathrm{pH}$ sheets. After that, app will displays the cleanness of foods by the indicating whether this is fresh, excellent, or ruined. And Figure 5 depicts the app's findings as shown on the phone's screen. 


\section{Authenticity of food:}

Another examples of creating sensor for loT sensor surface is the use of Spectroscopy spectroscopy to the distinguish not halal meats from the halal meats, which is required for the Muslims to consume. The information gathered by the FTIRs sensors may be the sent straight from communications layer to application layer, allowing customers or supervisor to see what kind of meat was used. In a wide variety of mid infrared spectroscopic range from the 400 to $4000 \mathrm{~cm}-1$, FTIR was utilized to distinguish pig fat from cow, chicken, or lamb fats. The findings of the study are described in detail earlier in. At wavenumber $2361.05 \mathrm{~cm}-1$, the results were obtained.

\section{LITERATURE REVIEW}

Chen et al. studied about Generally, food safety and quality concerns arise as a result of problems with food product handling and processing. It sparked a surge of interest in creating food supply chain traceability systems. Modeling the tracing process in compared to "automation" is currently limited, but little study has been undertaken where products issue information's is connected to the root of the problems or responsibility attribution at the very same time. Using FCM or a fuzzy rule methodology, this research offers an autonomous agent based tracing systems for products usage life cycle based on loT (internets of things) architecture. A research model for just an agricultural foods product is discussed. Its purpose was to apply the total effects technique to simulate complex food tracing systems with imperfect linkages while analyzing the influence of backward designing productivity improvement on performance ${ }^{[8]}$.

Liu, et al studied about The Internet of Things (IOT) has a lot of promise for ensuring the safety and quality of agricultural goods. The foundation of such loT technologies is convenient or efficient identifications or naming services (NS). This paper proposes iotNS, an enterprise oriented name service for loT applications in agricultural goods. The iotNS lowers the object name service's complexity while increasing access effectiveness. Based on the iotNS, an loT application for agricultural goods is built and implemented in real-world situations ${ }^{[10]}$.

\section{DIscussion}

As food is the most important source of energy for all living creatures, food quality or reliability have always been in short supply throughout history. The Internets of Things is technology that seeks to the connected anything at the any time, everywhere. IOT in foods supply chains is believe to the improve qualities of the life's by tracking and monitoring foods condition as well as live-sharing the obtain information with consumer and FSC supervisor. Foods quality or safety are grabbing the focus of the both governments actions or customers owed to obvious significant loss of state income and 
also the health concerns to consumers posed by the noncompliance with the food rules. As a consequence, developing technology that ensures food safety across the whole foods supply chain (FSC), which includes productions, dispensation, packing, transportations, storages, distributions, or consumer sale, is essential. With the advent of technologies such as the internet of things many studies have been conducted across the world to help businesses in addressing foods quality or safety issues. The cleanness of foods may be evaluated by evaluating pictures of foods or comparing it to a comparison photo, according to the mobile applications created for sensor layers of Internet of Things technologies. And the conditions of foods, whether the fresh, great, and rotting, may be the transmitted to all customers including foods supervisor through to networks levels of the IOT technology.

\section{CONCLUSION}

Food quality and consistency have always been in short supply throughout history, since food is the most essential source of energy for all living things. The Internets of Thing is a tool that aims to link everything, everywhere, at any time. By monitoring and controlling foods conditions then lives sharing's the acquired information with customers or the FSC administrators, IOT in foods supply chains is thought to improve the excellence of the lifetime. Food safety and security are attracting the attention of both government entities but also customers because of the significant loss of state income as well as the health hazards to consumers posed by noncompliance with food regulations. The concept of using the internets of thing for the agricultural, foods qualities or safety was proposed in this article. As per a mobile applications designed for the sensing's layers of Internet of Things technologies, the freshness of foods may be determined by analyzing the image of foods as well as comparing it to a source images. The status of the foods, if it is fresh, wonderful, or rotting, might well be conveyed to all customers including foods supervisors via the network or applications layers of the IOT technology. 


\section{REFERENCES:}

[1] Kemenkes RI, "Pedoman Strategi Komunikasi Perubahan Perilaku Dalam Percepatan Pencegahan Stunting Di Indonesia," Kementeri. Kesehat. Republik Indones., 2018.

[2] M. Aazam et al., "'Estudio de dos tipos de fertilizantes químicos y orgánicos en dos híbridos comerciales de pimiento (Capsicum annun L.) en la parte alta de la Cuenca del Río Guayas," Univ. TÉCNICA ESTATAL QUEVEDO Fac. CIENCIAS Agrar. Esc. Ing. AGRONÓMICA, 2015.

[3] K. Govindan et al., "Industry Surveys IT Consulting \& Other Services.," J. Clean. Prod., 2018.

[4] E. Hitimana, G. Bajpai, R. Musabe, and L. Sibomana, "Remote Monitoring and Control of Poultry Farm using loT Techniques," Int. J. Latest Technol. Eng., 2018.

[5] D. Wang, X. Rao, and Y. Ying, "Development of agri-products traceability in main developed agriculture region of the world," Nongye Gongcheng Xuebao/Transactions Chinese Soc. Agric. Eng., 2014, doi: 10.3969/j.issn.10026819.2014.08.028.

[6] G. Witjaksono, A. A. Saeed Rabih, N. B. Yahya, and S. Alva, "IOT for Agriculture: Food Quality and Safety," IOP Conf. Ser. Mater. Sci. Eng., vol. 343, no. 1, 2018, doi: 10.1088/1757-899X/343/1/012023.

[7] H. Brown, "The Internet of Things and the Future of Food," Food Industry News. 2016.

[8] R. Y. Chen, "Autonomous tracing system for backward design in food supply chain," Food Control, 2015, doi: 10.1016/j.foodcont.2014.11.004.

[9] F. T. Davies and B. Garrett, "Technology for Sustainable Urban Food Ecosystems in the Developing World: Strengthening the Nexus of Food-Water-EnergyNutrition," Front. Sustain. Food Syst., 2018, doi: 10.3389/fsufs.2018.00084.

[10] Y. Liu et al., "Enterprise-oriented iot name service for agriculture product supply chain management," 2014, doi: 10.1109/IIKI.2014.55.

\section{END}

